\title{
Two contrasting summer monsoon seasons in the recent past decade - an observational study
}

\author{
A. DHARMA RAJU*, C.V. NAIDU ${ }^{\$}$, RAMA KRISHNA KARUMURI ${ }^{\#}$, S. V. J. KUMAR*, K. \\ NAGA RATNA * \\ *India Meteorological Department, \\ ${ }^{\$}$ Dept of Meteorology and Oceanography, College of Science and Technology, Andhra \\ University, Visakhapatnam \\ ${ }^{\#}$ King Abdullah University of Science and Technology, Thuwal, Saudi Arabia.
}

\begin{abstract}
:
India experienced two extreme summer monsoons, 2007 (active monsoon) and 2009 (weak monsoon) in the recent past decade. The characteristic features of these two contrasting Indian summer monsoons have been presented. The country received $11.8 \%$ excess and $17.1 \%$ deficit rainfall during 2007 and 2009 monsoon seasons respectively. These large deviations in rainfall encourage us to study the influence of meteorological factors on rainfall activity. The distributions of rainfall over India, Latent Heat Flux, wind, Vertically Integrated Moisture Transport (VIMT), and Vertically Integrated Moisture Divergence (VIMD) values in the layer $1000 \mathrm{hPa}-300 \mathrm{hPa}$ for the domain, $0^{0}-40^{\circ} \mathrm{N}, 40^{\circ} \mathrm{E}-120^{\circ} \mathrm{E}$ in the two contrasting monsoon seasons are evaluated.In active monsoon, (i) predominant low level southwesterly flow over the Arabian sea and deflection of winds over the Bay of Bengal, strengthening of tropical easterly jet stream, wide area extent of easterlies in the upper troposphere, the maximum strength of easterlies in the upper troposphere $(150 \mathrm{hPa})$ isobserved over the area around $10^{0} \mathrm{~N}-15^{0} \mathrm{~N}$ and $70^{\circ} \mathrm{E}-75^{0} \mathrm{E}$; (ii)Position of subtropical ridge is more northward i.e. $32^{0} \mathrm{~N}$, (iii) a predominant moisture transport in the layer $1000 \mathrm{hPa}-300 \mathrm{hPa}$ from Southern Hemisphere, Arabian Sea and the Bay of Bengal to the Indian mainland, Westward/northward transport of moisture and area coverage of
\end{abstract}


larger quantum of moisture flux is seen and (iv) India experienced more number of mesoscale systems. The reverse is true for weak monsoon. Positive (neutral) Indian Ocean Dipole (IOD) and La-Nina (El Nino) conditions lead to active (poor) summer monsoon conditions over India in 2007 (2009) year.

Keywords: Monsoon, Vertically Integrated Moisture Transport (VIMT) Latent Heat Flux (LHF) and Vertically Integrated Moisture Divergence (VIMD)

\section{Introduction:}

Indian agriculture is mainly rain-dependent and the mainstay of the Indian economy. Seasonal rains are very much crucial for sustenance of agriculture and the farming community. Monsoon rains are the lifeline of Indian agriculture and its economy. Vagaries of monsoon play as havoc with the Indian economy and hence Indian economy is called "a gamble on the monsoons".

Studies by Parthasarathy et al., 1988; Webster et al., 1998; Abrol and Gadgil, 1999 and Gadgil 2003 indicated a strong relationship between the inter-annual variation of the rainfall and the food production in India. Parthasarathy and Mooley, 1978, and Mooley and Shukla, 1987 highlighted the inter-annual variation of rainfall from the long-term average rainfall as manifested in the form of floods and droughts which caused a devastating impact on the economy of the people. There is an increasing trend in the inconsistency of daily rainfall activity due to an increase in the frequency of extreme events in the global warming era (Vinay Kumar et al, 2019).

Longtime back, the teleconnections between ISMR and ENSO has been established. The deficit in Indian Summer Monsoon Rainfall (ISMR) and the droughts are linked to El Nino (Wyrtki, 1975) and (Ramussen \& Carpenter, 1983); to a coupled El Nino (Bjerknes, 1969); to 
warm Sea Surface Temperature (SST) in central Pacific than Eastern Pacific during El Nino years (Krishnakumar, 2006).

The IOD, also known as the Indian Ocean Nino, has an unmistakable influence on the ISMR (Saji et al., 1999). The positive (negative) IOD has an asymmetric positive (negative) impact on the ISMR. There is a large convection and an in-phase barotropic wave train response during the positive IOD, while this mode is not evident in negative flavour of the IOD (Qiu et al., 2014). Reversal of SST gradient between the Bay of Bengal (BOB) and the Eastern Equatorial Indian Ocean (EEIO) plays an important role in the reduction of rainfall over the BOB and hence over the Indian landmass. Equatorial Indian Ocean Oscillation (EQUINOO) is an important atmospheric component of the coupled IOD mode which leads to enhanced/suppressed cloud formation and hence rainfall (Gadgil et al., 2004, 2009). There is a significant positive correlation between ISMR and positive phase of EQUINOO (Charlotte, 2012); Anomalies of ISMR are related to EQUINOO between enhancement/suppression of convection of WEIO and suppression/enhancement over the SEIO. Using Nino 3 index and the IODMI, Ashok et al., (2003 and 2004) demonstrated that the IOD while significantly enhancing ISMR, it concurrently reduces the impact of the ENSO. The relationship between rainfall over South Asia and IOD is significant (Kripalani and Kumar 2004).

Progression of monsoon is paused by stagnations and hiatuses; the shift of rainfall belts during breaks in the monsoon causes intra-seasonal variations, differences in precipitation over different regions and also inter-annual variations of rainfall over the country (Ramamurthy, 1969; Raghavan, 1973; Krishnamurti and Bhalme, 1976; Sikka, 1980; Alexander et al., 1978). Despite the recent theories of several scientists revealing ENSO's decreasing influence on the Indian summer monsoon, there seems to be an impact of Eastern Pacific (EP) flavor of El Niño-Southern 
Oscillation (ENSO) (as in the case of 2007) with a stronger positive bearing on the ISMR, while the Central Pacific type (CP) (as in the case of 2009) with a negative influence on the ISMR (JinYi Yu and Seon Tae Kim et al., 2013). The decrease in the Indian summer monsoon is associated with warm phases of ENSO due to an anomalous regional Hadley circulation with descending motion over the Indian subcontinent and ascending motion near the equator sustained by the ascending phase of the anomalous Walker circulation in the equatorial Indian Ocean (Krishnamurthy and Goswami, 2000).

The tropical Indian Ocean (TIO) SST exhibits (i) El Niño induced strong basin wide warming over TIO i.e., Indian Ocean Basin Mode (IOBM; Klein et al. 1999; Chowdary and Gnanaseelan 2007; Yang et al. 2007) and (ii) east west SST dipole pattern known as IOD (Saji et al. 1999; Webster et al. 1999; Murtugudde et al. 2000). IOBM affects the rainfall activity over Asia (Izumo et al. 2008; Wu et al.2008). According Shukla 1975; Izumo et al. 2008, SST anomalies over the Arabian Sea and the southwest TIO affect the ISMR variability. Indo-Pacific climate displays remarkable changes after the mid-1970s climate shift (Nitta and Yamada 1989; Trenberth and Hurrell 1994). After the climate shift anomalous warming first appears over the central equatorial Pacific and spreads towards the eastern Pacific (Wang 1995). After the climate shift the frequency of central Pacific El Niño i.e., El Niño Modoki (Ashok et al. 2007) or central Pacific El Niño (Yeh et al. 2009) increased. After the mid-1970's climate shifts El Niño and IOD co-occurred more frequently with an east-west gradient in TIO SST anomalies (Annamalai et al. 2005) whereas the basin wide warming is prominent prior to the regime shift (Chakravorty et al. 2014a). Prominent warming over Arabian Sea is observed in summer during the onset phase of El Niño in pre-1976. A delayed warming in north Indian Ocean (NIO) is noticed after 1976 (Chakravorty et al. 2014a). The persistency of TIO warming for one season more (up to the following summer) during recent decades may cause high impact on the summer monsoon rainfall 
(Xie et al. 2010; Chakravorty et al. 2014a, b). The decline in the ENSO-Monsoon relationship after the mid-1970's climate shift is addressed (Kumar et al. 1999; Kinter et al. 2002). The NWP circulation shows profound influence on ISMR (Chowdary et al. 2013). The role of TIO acts as key factor in weakening the Pacific impact on ISMR (Chowdary et al. 2015).

Chakravorty et al (2016) found that ISMR anomalies during El Niño developing summer in epoch-1 (1950-1979) are mainly driven by El Niño forcing throughout the season, whereas TIO SST exhibits only a passive influence. On the other hand, in epoch-2 (1980-2009) ISMR does not show any significant relation with Pacific during the onset phase of monsoon whereas withdrawal phase is strongly influenced by El Niño. Again, the eastern Indian Ocean cooling and westward shift in northwest Pacific (NWP) cyclonic circulation during epoch-2 have strong positive influence on the rainfall over the central and eastern India during the matured phase of monsoon. The moisture convergence and moisture advection are very weak (strong) over Indian land mass during epoch-1 (epoch-2) in El Niño decaying summer. The changing moisture availability and convergence play important role in explaining the weakening of ENSO monsoon relation in the recent years. The local TIO SST forcing and NWP circulation are prominent forcing factors for the interannual variability of ISMR during epoch-2.

Indian Ocean Dipole (IOD) plays a crucial role in modulating the Indian monsoon rainfall and influences the ENSO-Indian SM rainfall relationship (Ashok and Zhaoyong, 2004). Further, spring North Atlantic Oscillation Index is inversely related with the Indian SM rainfall (Bhatla et al., 2016). According to Behera and Ratnam (2018), the moisture transports during positive IOD strengthen the monsoon trough and the meridional-monsoon circulation. This gives rise to abundant rainfall around the monsoon trough through an intensified monsoon-Hadley circulation but below normal rainfall south and north of the trough forming a distinct meridional tripolar pattern in the rainfall anomalies. The situation is different in the negative IOD case when the 
atmospheric responses and the moisture distribution favor moisture divergence in the eastern part but moisture convergence in the western part of the country. Also, besides, a zonal circulation cell is seen with anomalously rising air over the South China Sea and subsidence over eastern parts of India. Those give rise to abundant rainfall on the western part and form a zonal dipole with the drier eastern part. In addition to these, Arctic oscillation and mid tropospheric zonal wind anomaly over cluster region $\left[60^{\circ} \mathrm{N}-70^{\circ} \mathrm{N} ; 5^{\circ} \mathrm{W}-55^{\circ} \mathrm{W}\right]$ are directly correlated with each other in the winter season and this relationship in turn influences ISMR (Kakade and Kulakarni, 2017).

Intra-seasonal and inter-annual oscillations are intrinsic to the monsoons. The Indian summer/southwest monsoon rainfall has large variations viz., inter-annual, intra-seasonal and multi-epochal time scales. These variations are highlighted by many researchers (Ramage, 1971; Rao, 1976). While the long period changes impact the climate of the country, the intra-seasonal variations have a telling effect on various sectors especially agriculture, irrigation, hydro-electric power, economy and ground water. It has been observed that in the recent years, more so in the warming era, there have been large spatial and temporal variations in the monsoon rainfall.

The previous studies specify that evaporation over the Arabian Sea is about two to three times higher during the active monsoon period as compared to break monsoon period (Holt and Raman, 1986). The latent heat flux shows a marked peak around onset time between $50^{0}-55^{\circ} \mathrm{E}$ in the equatorial Indian Ocean belt and a decrease from $200 \mathrm{~W} / \mathrm{m}^{2}$ to $30 \mathrm{~W} / \mathrm{m}^{2}$ after the onset period (Simon and Desai, 1986). The winds over western Arabian Sea are about $2 \mathrm{~m} / \mathrm{s}$ higher in active monsoon than in poor monsoon. The core of the low-level jet is directed to the India $\left(5^{0} \mathrm{~N}-15^{0} \mathrm{~N}\right)$ producing heavy rainfall over Indiain active monsoon periods. The jet bypasses India in weak monsoon conditions (Swapna and Ramesh Kumar, 2002). 
In the global warming period, the conditions over the Bay of Bengal are not encouraging for the formation of monsoon depressions in the summer monsoon season (Vishnu et al. 2016). The frequency of monsoon depressions (MD) is decreasing year by year. Vinay Kumar et al. (2020) reported a significant reduction in the frequency of cyclonic disturbances forming over the North Indian Ocean and land area during summer monsoon season in the global warming environment, declining genesis potential parameter over the Bay of Bengal, a decrease in the moisture in the mid troposphere over the Bay of Bengal which may be responsible for the formation of less number of cyclonic disturbances and the anomalous descent which inhibits the rainfall activity over India. As MDsare the chief contributors to the Indian Summer Monsoon Rainfall (ISMR) regime, the decreasing frequency of these systems has a bearing on the seasonal rainfall over the country as a whole. This is evident in the monsoon seasonal rainfall amounts in the years 2007 (active) and 2009 (weak) in the recent past decade. With this intent, a study is undertaken to analyze the nature of the two contrasting monsoon seasons.

Availability of copious amounts of moisture in the lower and mid-tropospheric levels, the strong southwesterly streamline flow, winds at various levels and moisture transport translate in to rainfall. Hence, the winds and moisture patterns at various levels during these contrasting monsoons are analyzed and the observations are appraised in the present study to draw out the causative factors of this conspicuous difference in the characteristics of monsoon. As a part of the study, theauthors also emphasize the influence on the monsoon rain oflatent heat flux whichshows the loss of heat through evaporation at the sea surface.

According to Zhu, 2012, the Find later jet, cross-equatorial flow and horizontal temperature gradient contribute to the transport of moisture and the monsoon current on to the Indian landmass. So, the winddistributions at lower $(850 \mathrm{hPa})$ and upper $(150 \mathrm{hPa})$ tropospheric 
level over the domain $\left(0^{0}-40^{\circ} \mathrm{N}\right.$ and $\left.40^{\circ} \mathrm{E}-120^{\circ} \mathrm{E}\right)$ are studied for the two seasons. The hydrological aspects (Cadet et al.,1981, Fasullo and Webster,2003) enable us to find the availability of sustained moisturethat can be realized in the form of rainfall. The rainfall over the country exceeds water vapor because of the lateral transport and advection of moisture. This is seen from the visualizations of Vertically Integrated Moisture Transport. The eastward vector indicates the moisture transport from the west over to the major convection centers of the country. The convergence of moisture from the source regions of Arabian Sea and Bay of Bengal can be observed from the Vertically Integrated Moisture Divergence (VIMD) for the weak monsoon (2009) and active monsoon (2007).

\section{Data and Methodology:}

The rainfall data in June, July, August and September over India as a whole and 30 meteorological sub-divisions (Figure 1a) during 1953-2012 is taken from the Indian Institute of Tropical Meteorology (IITM) website (www.tropmet.res.in). The hilly regions have not been considered due to sparse rain-gauge network. The island regions have not been taken to maintain contiguity.

The long-term (1953-2012) mean of the all-India summer monsoon rainfall (AISMR) (area-weighted average of 30 meteorological subdivisions) is $841.6 \mathrm{~mm}$ with a standard deviation of $85.28 \mathrm{~mm}$. If the summer monsoon rainfall over India exceeds/equals to mean plus one standard deviation, that monsoonis considered as active monsoon. If AISMR precedes/equals to mean minus one standard deviation, that monsoon is considered as weak monsoon. India has experienced ten active monsoon years $(1955,1956,1961,1959,1970,1975,1988,1983,1994$, 2007) and twelve weak monsoons (1965, 1966, 1968, 1972, 1974, 1979, 1982, 1986, 1987, 2002, 2004, 2009) during the study period (Figure 1b). We have considered two extreme cases in the 
recent past decade (active monsoon in 2007 and weak monsoon in 2009). India experienced a normal monsoon in the year (2008) between these two extremes.

Using the NCEP-NCAR reanalysis data, the distributions of latent heat flux, vertically integrated moisture flux\&vertically integrated moisture divergence andwindpatterns for active monsoon (2007) and poor monsoon (2009), and their differences (2007 pattern minus 2009 pattern) over the domain, $0^{0}-40^{\circ} \mathrm{N}, 40^{\circ} \mathrm{E}-120^{\circ} \mathrm{E}$ areanalyzed. The data includes wind, latent heat flux and specific humidity.

The vertically integrated moisture flux $(Q)$ can be expressed as

$$
Q=\frac{1}{g} \int_{p}^{p s} q V d p
$$

The vertically integrated moisture divergencewas computed following Trenberth and Guillemot (1998):

$$
\nabla \cdot Q=\nabla \cdot \frac{1}{g} \int_{p}^{p s} q V d p
$$

where $q$ is the specific humidity, $p$ is the pressure at the top of the atmosphere, $p \mathrm{~s}$ is the surface pressure, $V$ is the wind vector, and $g$ is the acceleration due to gravity. According to Fasullo and Webster (2003), the vertically integrated moisture transport as well as the specific humidity above $300 \mathrm{hPalevel}$ is negligible; it is not a part of the reanalysis by Kalnay et al., 1996. Vertically Integrated Moisture Transport (VIMT) and Vertically Integrated Moisture Divergence (VIMD) for both these extreme monsoon seasons (JJAS 2007 and 2009) were calculated for the layer 1000 $\mathrm{hPa}-300 \mathrm{hPa}$. 
The impact of the ENSO and the IOD on the ISMR for the years 2007 and 2009 is evaluated using the SST data sets (http://esrl.noaa.gov/psd/data/climateindices/list/) of Oceanic Niño Index (ONI) over the Niño 3.4 region(i.e., $\left.5^{\circ} \mathrm{N}-5^{\circ} \mathrm{S}, 120^{\circ}-170^{\circ} \mathrm{W}\right)$. To understand the impact of Dipole Mode Index (DMI), we evaluated the SST data (http://www.jamstec.go.jp/frcgc/research/d1/iod/DATA/dmi_HadISST.txt) over the Indian oceanic region is used in this study.

\section{Results and Discussions}

\subsection{Rainfall distribution:}

Rainfall distribution over different subdivisions is very much significant as the seasonal rainfall over a region is the main discretionary factor of agricultural operations. Hence, the rainfall distribution both in space and time subdivision-wise and month-wise are evaluated.

June: The rainfall amounts in June for two extremes along with their differences (rainfall in June 2007 minus rainfall in June 2009) are shown in Figure2.In all subdivisions, (except Tamil Nadu \& Pondicherry and West Rajasthan) there is an enhanced rainfall activity in June 2007 than in June 2009. Coastal Karnataka (563 mm) and Konkan \& Goa (536 mm) recorded huge rainfall differences than any other subdivisions. Two subdivisions, Chhattisgarh and Orissa recorded very high differences of $247 \mathrm{~mm}$ and $221 \mathrm{~mm}$ respectively. It is $192 \mathrm{~mm}$ over Kerala. The differences are also high over Coastal Andhra Pradesh, Rayalaseema, Jharkhand, North Interior Karnataka and Madhya Maharashtra (116 mm to191mm). It is negligible over Rajasthan region. In June, monsoon may not enter into Rajasthan area. At the time of onset of summer monsoon over Tamil Nadu region, many stations over that region may not show a quick raise in the rainfall due to rainshadow effect. 
July: July is the principal rainy month. Every part of India experience rainfall activity. In general, summer monsoon contributes 2000 to $2500 \mathrm{~mm}$ rainfall over the west coast of India. But, inJuly 2007 the west-coast and the adjoining subdivisions namely, Coastal Karnataka, Konkan\& Goa, Saurashtra, Kutch \& Diu received very less amounts of rainfall with huge negative differences of $-680 \mathrm{~mm},-244 \mathrm{~mm}$ and $-161 \mathrm{~mm}$ respectively. The region comprising of contiguous and adjoining subdivisions of Orissa (-398mm), Chhattisgarh (-99 mm), East Madhya Pradesh $(-82 \mathrm{~mm})$; Punjab $(-83 \mathrm{~mm})$, South Interior Karnataka $(-43 \mathrm{~mm})$ and Haryana $(-33 \mathrm{~mm})$ recordedsubdued amounts of rainfall in 2007 than in 2009. West and East Rajasthan, Madhya Maharashtra, Marathwada and North Interior Karnataka also received less rainfall in 2007 than in 2009. The rest of India (16 subdivisions) experienced excess rainfall amounts in July 2007 than in July 2009 (Figure3).

August: In August 2007, all the subdivisions (except two subdivisions of Northeast India, Assam \& Meghalaya (-115 mm) and Nagaland, Manipur, Mizoram \& Tripura (-97 mm), East Madhya Pradesh (-11 mm), Coastal Andhra Pradesh (-10 mm), Uttar Pradesh and Marathwada) received high amounts of rainfall when compared to August 2009. Here, the west-coast subdivisions showed largepositive differences over Konkan \& Goa (640 mm), Coastal Karnataka (340 mm), Saurasthra \& Kutch $(285 \mathrm{~mm})$ and Gujarat $(253 \mathrm{~mm})$. The subdivisions namely Orissa (145 mm), Rayalaseema $(131 \mathrm{~mm})$ and Vidarbha $(115 \mathrm{~mm})$ showed enhanced rainfall activity. This type of pattern of less amounts of rainfall over northeast India and high amounts of rainfall over the rest of India indicates clearly the presence of active monsoon conditions over the main and core zones in August 2007. Reverse is true for August 2009. In general, Northeast India acts as a unique homogeneous region with respect to rainfall activity (Figure 4). 
September: In this month, three isolated contiguous regions recorded reduced rainfall in 2007 monsoon season than in 2009. The first region comprises of Punjab (-42 mm), Haryana, Chandigarh\& Delhi (-119 mm), East Uttar Pradesh $(-32 \mathrm{~mm})$ and West Uttar Pradesh (-85 mm) with huge rainfall differences; the second has East Madhya Pradesh and West Madhya Pradesh and the third comprises of North Interior Karnataka, South Interior Karnataka and Tamil Nadu. Remaining sub-divisionsreported high rainfall in September 2007 in contrast to September 2009 (Figure 5).

Summer monsoon season (June - September): In 2007 summer monsoon season, twenty-seven subdivisions reported high rainfall than in 2009. Only threesubdivisions namely Punjab, Haryana, Chandigarh\& Delhi and East Madhya Pradesh showed subdued rainfall activityin 2007. There are quite high positive differences $(350 \mathrm{~mm}$ to $1111 \mathrm{~mm})$ over the subdivisions of west coast and adjoining subdivisions of Gujarat. The differences are high over Gangetic West Bengal (709 mm), Bihar (534 mm), Vidarbha (541 mm), Chattisgarh (386 mm) and Jharkhand (346 mm). Over Telangana and Rayalaseema, the deviations range from $316 \mathrm{~mm}$ to $355 \mathrm{~mm}$. More or less the same types of deviations are observed over Gangetic West Bengal\& Sikkim $(333 \mathrm{~mm})$ and Assam \& Meghalaya $(373 \mathrm{~mm})$. The deviations ranging from $208 \mathrm{~mm}$ to $385 \mathrm{~mm}$ are over Coastal Andhra Pradesh, Marathwada, Chhattisgarh, and Orissaand from 168 mm to $228 \mathrm{~mm}$ over West Madhya Pradesh, North Interior Karnataka and Madhya Maharashtra. Slight deviations are observed over the remaining subdivisions (Figure 6).

The AISMR in 2007 monsoon season is $935.0 \mathrm{~mm}$ with $11.1 \%$ deviation of the rainfall from the mean and normalized value of 1.1. Two cyclonic systems formed over Arabian Sea in June 2007. Five depressions formed, four over Bay of Bengal and one over the Bangladesh coast; two depressions formed in June and one each in July, August and September. Six low pressure 
areas/well marked low pressure areas (LPA) formed, one in July, two in August and three in September. Five of them formed over Bay of Bengal and one over Arabian Sea. Most of them originated as upper air cyclonic circulations. All of them moved in land except one. Off-shore trough along different parts of the west coast persisted on most of the days from 28 May to 30 September except for 10 days (IMD, monsoon report for 2007).

The AISMR in 2009 monsoon season is $667.6 \mathrm{~mm}$ with $-20.7 \%$ deviation and normalized value of -2.04. Four depressions and 5 low pressure areas are formed. The average life of these systems is less over the land. They are unable to create good amounts of rainfall over Indian mainland. In June, two depressions over Arabian Sea and one low pressure area over Bay of Bengal formed. In July, the synoptic activity was near normal. Two LPAs and one deep depression formed over NW Bay of Bengal created excess rainfall over west coast and central parts. In August, one LPAformed over Bay of Bengal. In September, one deep depression over NW Bay of Bengal and one LPA over WC Bay of Bengal formed (IMD, monsoon report for 2009).

\subsection{LATENT HEAT FLUX(LHF):}

Latent heat is an important thermodynamic energy parameter. The kinetic energy manifests in the form of latent heat, helps in the release or loss of energy which triggers the airsea interaction. The heat transfer takes place from ocean to the atmosphere with the latent heat as a flux.

The LHF distributions for active monsoon season, 2007 and weak monsoon season, 2009, and their differences (pattern in 2007 monsoon season minus pattern in 2009monsoon season) are presented in Figure.7. The LHF magnitudes in JJAS of 2007 arehigh over major part of India north of $15^{0} \mathrm{~N}$ (differences, 2 to $22 \mathrm{w} / \mathrm{m}^{2}$ ) as well as oceanic area and oceanic area off Somalia 
Coast $\left(10\right.$ to $30 \mathrm{w} / \mathrm{m}^{2}$ ) when compared to that of the 2009 monsoon period. Particularly, the positive anomalies of latent heat flux over $17^{0} \mathrm{~N}$ to $25^{\circ} \mathrm{N}, 55^{\circ} \mathrm{E}$ to $95^{\circ} \mathrm{E}$, the Indian landmass region are high. Major part of northern Arabian Sea and northern Bay of Bengal area showed positive values. Major part of equatorial North Indian Ocean and southern parts of India and surrounding oceanic region show negative anomalies $\left(-10\right.$ to $\left.-30 \mathrm{w} / \mathrm{m}^{2}\right)$. Release of latent heat enhances the north-south temperature gradient and hence monsoon meridional circulation and the zonal winds during active monsoon, so winds strengthen in the upper troposphere. The enhanced north-south temperature gradient may be responsible for the strengthening of tropical easterly jet stream at the upper troposphere during active monsoon (Naidu et al., 2011). Ramanadham et al. (1981) observed that the average latent heat flux over the Arabian Sea during normal monsoon conditions is $129 \mathrm{w} / \mathrm{m}^{2}$ and is quite high over the Arabian Sea than any other parts of the North Indian Ocean. LHF shows the loss of heat through evaporation at the sea surface. Previous studies demonstrate that evaporation over the Arabian Sea is about two to three times higher during the active monsoon period as compared to break monsoon period (Holt and Raman, 1986). The LHF shows a marked peak around onset time between $50^{\circ}-55^{\circ} \mathrm{E}$ in the equatorial Indian Ocean belt and a decrease from $200 \mathrm{~W} / \mathrm{m}^{2}$ to $30 \mathrm{~W} / \mathrm{m}^{2}$ after the onset period (Simon and Desai, 1986).

\subsection{Wind pattern at $850 \mathrm{hPa}$ :}

Summer monsoon season: The low-level circulation patterns $(850 \mathrm{hPa})$ in summer monsoon season in 2007 and 2009 are presented in Figure.8. In whole monsoon season as well as the individual months in 2007 (figures not shown), the anomaly wind patterns clearly indicate the presence of (i) strong southwesterly flow from Arabian Sea, (ii) southeasterly flow from Bay of Bengal and (iii) anomalous cyclonic cell over Gujarat and Saurashtra, Kutch \& Diu area. This is an evidence of strong low-level flow whichis favorable for active monsoon in 2007 when 
compared to that of 2009. It seems that the intrusion of subtropical westerlies is the causative factor for weak monsoon in 2009 (Figure 8).

\subsection{Wind pattern at $150 \mathrm{hPa}$}

Summer monsoon Season: In monsoon season, the easterlies with a strength of about 30 $\mathrm{m} / \mathrm{s}$ are present over the $10^{0}-15^{0} \mathrm{~N}$ latitude beltover India and surrounding oceanic area in 2007 . But the maximum intensity in the easterlies in 2009 shifted eastward and located over Andaman and Nicobar Islands and adjoining Malay Peninsula area. The subtropical ridge in Northern Hemisphere is located relatively in northern latitudes $\left(30-35^{0} \mathrm{~N}\right)$ in 2007 monsoon when compared to $2009\left(27^{0}-30^{0} \mathrm{~N}\right)$; particularly the shiftingof subtropical ridge in the westernparts is more. There is an anomalous cyclonic circulation over South China, which indicates the enhanced/reduced anti-cyclonic circulation in weak/active monsoon over that region. The anomalous easterlies over south Arabian Sea (Figure9) clearly designate the prevalence of a broad belt of intensified easterlies over southern latitudes of India and neighborhood in active monsoon.

\subsection{Vertically Integrated total Moisture Transport (VIMT) for the layer $1000 \mathrm{hPa}-$ $300 \mathrm{hPa}\left(\mathrm{Kg} \mathrm{m}^{-1} \mathrm{~s}^{-1}\right)$ :}

In monsoon season of 2007 and its individual months (figures not shown), the VIMT

values over Arabian Sea and Bay of Bengal are relatively high when compared to 2009 monsoon season. In particular, they are dominant over Arabian Sea in 2007. The VIMT values are high over Siam, Malay Peninsula \& adjoining Malaysia and surrounding region in 2009. The transport from Southern Hemisphere to Indian mainland through Somali jet is predominant in 2007. The moisture transport from Arabian Sea and Bay of Bengal are also high in 2007 (Figure10).

The anomaly patterns in summer monsoon seasonand its individual months clearly exhibit the role played by both Arabian Sea and Bay of Bengal and also Southern Hemisphere. 
Particularly more moisture is transported towards India from Arabian Sea and Bay of Bengal during 2007 summer monsoon season when compared to 2009. Also, the eastward transport flow from Bay of Bengal is also more in 2007. Moisture transport towards north India from both Arabian Sea and Bay of Bengal is enhanced apparently in 2007 season. The anomalous picture also depicts the crucial role of cross equatorial flow from Southern Hemisphere in monsoon season (Figure10).

\subsection{Vertically integrated moisture divergence (VIMD) for the layer $1000 \mathrm{hPa}-300 \mathrm{hPa}$ (in $\left.10^{-5} \mathrm{~kg} \mathrm{~m}^{-2} \mathrm{~s}^{-1}\right)$ ):}

In monsoon season of 2007 and the individual months (figures not shown), the area of convergence of moisture flux over India and neighborhood is more when compared to that of 2009 (Figure 11). The anomaly convergence is more over the Indian mainland north of $17^{0} \mathrm{~N}$. Northern parts of Bay of Bengal and major part of Arabian Sea specify anomaly divergence. Particularly sea area along the southern as well as northern parts of west coast shows anomaly convergence. This picture clearly indicates the dominance of moisture divergence from both Bay of Bengal and Arabian Sea in the active monsoon season, 2007 when compared to weak monsoon, 2009.

\subsection{Influence of the IOD and the ENSO on ISMR 2007 and 2009:}

Analysis of the ONI (Oceanic Nino Index) over the Nino 3.4 region and the DMI (Dipole Mode Index) for the monsoon seasons 2007 and 2009 indicates that the monsoon period of the year 2007 is a period of a cold anomaly (negative ONI below the threshold of -0.5) and positive IOD (with DMI above the threshold of +0.4 ); while the summer monsoon period of 2009 is a regime of warm anomaly (with ONI above the threshold of 0.5) and the neutral IOD (with DMI value between +0.4 and -0.4 ). 
The co-occurrence of cold anomaly of the ENSO and the positive IOD in 2007 contributed concurrently to help enhance the wind flow pattern, moisture convergence and hence high monsoon rainfall $(943 \mathrm{~mm})$. The warm anomaly and neutral IOD makes the monsoon 2009 a pure ENSO seasonal event and the El Nino during this season had unleashed its influence through suppression of convection and weak monsoon current to yield a reduced rainfall activity (698 $\mathrm{mm})$ over India.

\section{Conclusions:}

The following points can be concluded from the study. The interannual variations in summer monsoon rainfall over India exhibit two extreme summer monsoons 2007 (active) and 2009 (weak)during recent past decade, 2001-2010.The air-sea interaction is an important process for monsoon sustenance. High rainfall activity leads to release of more quantity of latent heat which plays a crucial role in enhancing the north-south temperature gradient (Naidu et.al 2011) as well as Indian summer monsoon circulation. Hence dominant lower and upper tropospheric circulations are evident in the active monsoon. The incursion of subtropical westerlies in the mid as well as upper troposphere during weak monsoon season suppresses the transport of moisture from the surrounding oceanic area to Indian mainland and inhibits the rainfall activity over India.A predominant moisture transport in the layer $1000 \mathrm{hPa}-300 \mathrm{hPa}$ from the surrounding oceanic area as well as Southern Hemisphere to Indian mainland is perceptible during active monsoon than in weak monsoon. Further, the moisture divergence over the surrounding oceanic area is more in active monsoon. Positive IOD and La-Nina (cold SST anomaly) lead to active summer monsoon conditions over India in 2007. The El Nino (warmSST anomaly) along with neutral IOD in 2009 affected India with deficit summer monsoon rainfall activity. 
Acknowledgement: The authors express their gratitude to the DGM, IMD for his encouragement. The authors are also grateful to the NCEP-NCAR for providing data resources. Thanks, are also due to anonymous reviewers without whose probing queries this work would not have been more refined and boiled to the crux.

\section{References:}

Abrol, Y. P., and S. Gadgil, Eds., 1999: Rice- in a Variable Climate. APC Publications Pvt Ltd, New Delhi,pp-243.

Alexander, G., R. Keshavamurty, U. De, R. Chellapa, S. Das, and P. Pillai, 1978: Fluctuations of monsoon activity. J. Met. Hydrol. Geophys, 29, 76-87.

Annamalai, H. and Liu, P., 2005. Response of the Asian summer monsoon to changes in El Niño properties. Quarterly Journal of the Royal Meteorological Society: A journal of the atmospheric sciences, applied meteorology and physical oceanography, 131(607), pp.805-831.

Ashok K, Zhaoyong G. 2004. Individual and combined influences of ENSO and the Indian Ocean dipole on the Indian summer monsoon. J. Clim. 17: 3141-3155.

Ashok, K., Behera, S.K., Rao, S.A., Weng, H. and Yamagata, T., 2007. El Niño Modoki and its possible teleconnection. Journal of Geophysical Research: Oceans, 112(C11).

Ashok, K., Guan, Z. and Yamagata, T., 2001, "Impact of the Indian Ocean Dipole on the relationship between the Indian Monsoon rainfall and ENSO", Geophys. Res. Lett., 26, 4499-4502.

Ashok, K., Guan, Z., Saji, N. H. and Yamagata, T., 2004, "Individual and Combined Influences of ENSO and the Indian Ocean Dipole on the Indian Summer Monsoon”, Geophys. Res. Lett., 26, 4499-4502.

Behera SK, Ratnam JV (2018) Quasi-asymmetric response of the Indian summer monsoon rainfall to opposite phases of the IOD. Scientific Reports 8:123. http://dx.doi.org/10.1038/s41598017-18396-6.

Bhatla R., Singh AK, Mandal B, Ghosh S, Pandey SN, Sarkar A. 2016. Influence of North Atlantic Oscillation on Indian Summer Monsoon Rainfall in Relation to Quasi-Binneal Oscillation. Pure Appl. Geophys. 173: 2959-2970.

Cadet, D., Reverdin, G., 1981. Water vapour transport over the Indian Ocean during summer 1975. Tellus, 33, 476-487. 
Chakravorty, S., Chowdary, J.S. and Gnanaseelan, C., 2014. Epochal changes in the seasonal evolution of tropical Indian Ocean warming associated with El Niño. Climate dynamics, 42(3-4), pp.805-822.

Chakravorty, S., Gnanaseelan, C. and Pillai, P.A., 2016. Combined influence of remote and local SST forcing on Indian Summer Monsoon Rainfall variability. Climate Dynamics, 47(9-10), pp.2817-2831.

Charlotte,B.V., Dhanya and Basil Mathew, 2012: EQUINOO: The entity and validity of this oscillation to Indian monsoon: RESEARCH INVENTY: International Journal of Engineering and Science ISBN: 2319-6483, ISSN: 2278-4721, Vol. 1, Issue 11, (December 2012), PP 45-54 www.researchinventy.com

Chowdary, J.S. and Gnanaseelan, C., 2007. Basin-wide warming of the Indian Ocean during El Niño and Indian Ocean dipole years. International Journal of Climatology: A Journal of the Royal Meteorological Society, 27(11), pp.1421-1438.

Chowdary, J.S., Gnanaseelan, C. and Chakravorty, S., 2013. Impact of northwest Pacific anticyclone on the Indian summer monsoon region. Theoretical and applied climatology, 113(12), pp.329-336.

Chowdary, J.S., Parekh, A., Ojha, S., Gnanaseelan, C. and Kakatkar, R., 2016. Impact of upper ocean processes and air-sea fluxes on seasonal SST biases over the tropical Indian Ocean in the NCEP Climate Forecasting System. International Journal of Climatology, 36(1), pp.188-207.

Fasullo, J. and P. J. Webster, 2003: A hydrological definition of the Indian summer monsoon onset and withdrawal. J. Climate, 16 (19), 3200-3211.

Gadgil, S., 2003: The Indian monsoon and its variability. Annu.Rev.EarthPlanet.Sci, 31, 429-467.

Gadgil, S., Vinayachandran, P. N., Francis, P. A. and Gadgil, S., 2004, "Extremes of the Indian summer monsoon rainfall: ENSO and equatorial Indian Ocean Oscillation”, Geoph. Res. Lett., 31, L12213, doi:10.1029 / 2004GLO19733.

Gadgil, S.., Francis., 2010: "Towards understanding the unusual Indian monsoon in 2009”, J. Earth Syst. Sci. 119, No. 4, August 2010, pp. 397-415

Holt, T., and Raman, S., A, 1987. Study of mean boundary layer structures over the Arabian Sea and Bay of Bengal during active and break monsoon periods, Bound. Layer Meteorol., 38, 73-94.

Izumo, T., Montégut, C.B., Luo, J.J., Behera, S.K., Masson, S. and Yamagata, T., 2008. The role of the western Arabian Sea upwelling in Indian monsoon rainfall variability. Journal of Climate, 21(21), pp.5603-5623.

Jin-Yi Yu* and Seon Tae Kim, 2013, Identifying the types of major El Nĩno events since 1870.Int. J. Climatol. 33: 2105-2112 (2013). 
Kakade S, Kulkarni A. 2017. Association between Arctic Circulation and Indian Summer Monsoon Rainfall. J. Climatol. Weather Forecasting 5:207.https://doi.org/10.4172/23322594.1000208.

Kalnay, E., and Coauthors, 1996: The NCEP/NCAR 40-Year Reanalysis Project. Bull. Amer. Meteor. Soc., 77, 437-471.

Kinter III, J.L., Miyakoda, K. and Yang, S., 2002. Recent change in the connection from the Asian monsoon to ENSO. Journal of Climate, 15(10), pp.1203-1215.

Klein, S.A., Soden, B.J. and Lau, N.C., 1999. Remote sea surface temperature variations during ENSO: Evidence for a tropical atmospheric bridge. Journal of climate, 12(4), pp.917-932.

Krishna Kumar, K., Rajagopalan, B., Hoerling, M., Bates, G. and Cane, M., 2006, "Unraveling the mystery of Indian monsoon failure during El Nino", Science, 314, 115-119.

Krishnamurthy, V. and Goswami, B.N., 2000: Indian monsoon-ENSO relationship on interdecadal time scale. J. Climate, 13, 579-595.

Krishnamurti, T. N., and H. N. Bhalme, 1976: Oscillations of monsoon system. Part I: Observational aspects. J. Atmos. Sci., 45, 1937-1954.

Kumar, K.K., Rajagopalan, B. and Cane, M.A., 1999. On the weakening relationship between the Indian monsoon and ENSO. Science, 284(5423), pp.2156-2159.

Mooley, D. A. and J. Shukla, 1987: Variability and forecasting of the summer monsoon rainfall over India. Monsoon Meteorology. Editors: C. P. Chang and T. N. Krishnamurti. Oxford University Press, 26-59.

Murtugudde, R., McCreary Jr, J.P. and Busalacchi, A.J., 2000. Oceanic processes associated with anomalous events in the Indian Ocean with relevance to 1997-1998. Journal of Geophysical Research: Oceans, 105(C2), pp.3295-3306.

Naidu, C.V., Muni Krishna, K., Ramalingeswara Rao, S., Bhanu Kumar, O.S.R.U., Durgalakshmi, K., Ramakrishna, S.S.V.S., 2011a. Variations of Indian summer monsoon rainfall induce the weakening of easterly jet stream in the warming environment? Glob. Planet. Chang. $75,21-30$.

Nitta, T. and Yamada, S., 1989. Recent warming of tropical sea surface temperature and its relationship to the Northern Hemisphere circulation. Journal of the Meteorological Society of Japan. Ser. II, 67(3), pp.375-383.

Parthasarathy B.A.,D. A. Mooley, Some Features of a Long Homogeneous Series of Indian Summer Monsoon Rainfall, 1978, Monthly Weather Review 106(6):771, DOI: 10.1175/15200493(1978)106-0771. 
Parthasarathy BA, A.A. Munot, D.R.Kothawale, (1988), Regression model for estimation of Indian food grain production from Indian summer rainfall, Agricultural and Forest Meteorology 42(2-3):167-182 DOI: 10.1016/0168-1923(88)90075-5.

Raghavan, K. (1973): Break monsoon over India. Mon. Weather Rev., 101, 33-43.

Ramage,C. S., 1971: Monsoon Meteorology. vol. 15 of International Geophysics Series, Academic Press,296pp.

Ramamurthy K. 1969. Monsoon of India: some aspects of the 'break' in the Indian southwestmonsoon during July and August. Forecast. Man. 18.3(No. IV):1-57. India Meteorol. Dept., Poona, India.

Ramanadham, R., S.V.S. Samanadham and R.R. Rao 1981. Heat budget of the northern indian Oceanic surface during monsoon-77. In: Monsoon Dynamics, (Eds. Lighhill and Pearce) Cambridge University Press, Cambridge. Pp. 1-735.

Rao, Y. P., 1976: Southwest Monsoon, India Meteorological Department, New Delhi, meteorological Monograph,366pp.

Saji, N.H., Goswami, B.N., Vinayachandran, P.N. and Yamagata, T., 1999. A dipole mode in the tropical Indian Ocean. Nature, 401(6751), pp.360-363. doi:10.1038/43854. PMID 16862108. S2CID 4427627.

Shukla, J., 1975. Effect of Arabian sea-surface temperature anomaly on Indian summer monsoon: A numerical experiment with the GFDL model. Journal of the Atmospheric Sciences, 32(3), pp.503-511.

Sikka, D. R., 1980: Some aspects of large-scale fluctuations of summer monsoon rainfall over India in relation to fluctuations in planetary and regional scale circulation parameters. Proc. Ind. Acad. Sci. (Earth \& Planetary Sciences), 89, 179-195.

Simon, B and Desai, P.S., 1986: Equatorial Indian Ocean evaporation estimates from operational meteorological satellites and some inferences in the context of monsoon onset and activity. Boundary Layer Meteorol., 37, 37-52.

Strauss, Kiladis, $2003 \quad$ https://doi.org/10.1175/15200469(2003)060\%3C3009:TIOWAC\%3E2.0.CO;2

Swapna, P. and Ramesh Kumar, M.R., 2002: Role of low-level flow on the summer monsoon rainfall over the Indian subcontinent during two contrasting monsoon years. Journal of Indian Geophysical Union, 6, 123-137.

Trenberth KE, Guillemot CJ (1998) Evaluation of the atmospheric moisture and hydrological cycle in the NCEP/NCAR reanalyses. ClimDyn 14(3):213-231. doi:10.1007/s003820050219. 
Trenberth, K.E. and Hurrell, J.W., 1994. Decadal atmosphere-ocean variations in the Pacific. Climate Dynamics, 9(6), pp.303-319.

Vinay Kumar, P., Naidu, C.V. and Prasanna, K 2019: Inconsistency in the frequency of rainfall events in the Indian summer monsoon season. International Journal of Climatology, https://doi.org/10.1002/joc.6113.

Vinay Kumar, P., Naidu, C.V. and Prasanna, K 2020: Recent unprecedented weakening of Indian summer monsoon in warming environment. Theoretical and Applied Climatology, 140, 467-486.

Vishnu S, Francis PA, Shenoi SSC, Ramakrishna SSVS (2016) On the decreasing trend of the number of monsoon depressions in the Bay of Bengal. Environ Res Lett 11. doi:10.1088/17489326/11/1/014011.

Wang, B., 1995. Interdecadal changes in El Nino onset in the last four decades. Journal of Climate, 8(2), pp.267-285.

Webster, P. J., V. Magaña, T. N. Palmer, J. Shukla, R. A. Tomas, M. Yanai, and T. Yasunari, Monsoons(1998): Processes, predictability and prospects for prediction, J. Geophys. Res., 103, $14,451-14,510$.

Webster, P.J., Moore, A.M., Loschnigg, J.P. and Leben, R.R., 1999. Coupled ocean-atmosphere dynamics in the Indian Ocean during 1997-98. Nature, 401(6751), pp.356-360.

Wu, R., Kirtman, B.P. and Krishnamurthy, V., 2008. An asymmetric mode of tropical Indian Ocean rainfall variability in boreal spring. Journal of Geophysical Research: Atmospheres, 113(D5).

Wyrtki, K., 1975, "El Niño-the dynamic response of the equatorial Pacific Ocean to atmospheric forcing", Journal of Physical Oceanography, 5, 572-583.

Xie, S.P., Du, Y., Huang, G., Zheng, X.T., Tokinaga, H., Hu, K. and Liu, Q., 2010. Decadal shift in El Niño influences on Indo-western Pacific and East Asian climate in the 1970s. Journal of Climate, 23(12), pp.3352-3368.

Yang, J., Liu, Q., Xie, S.P., Liu, Z. and Wu, L., 2007. Impact of the Indian Ocean SST basin mode on the Asian summer monsoon. Geophysical Research Letters, 34(2).

Yeh, S.W., Kug, J.S., Dewitte, B., Kwon, M.H., Kirtman, B.P. and Jin, F.F., 2009. El Niño in a changing climate. Nature, 461(7263), pp.511-514.

Zhu, Y., Variations of the summer Somali and Australia cross-equatorial flows and the implications for the Asian summer monsoon. Adv. Atmos. Sci., 2012, 29,509-518. 
Figures:

\section{Meteorological Subdivisions of India}
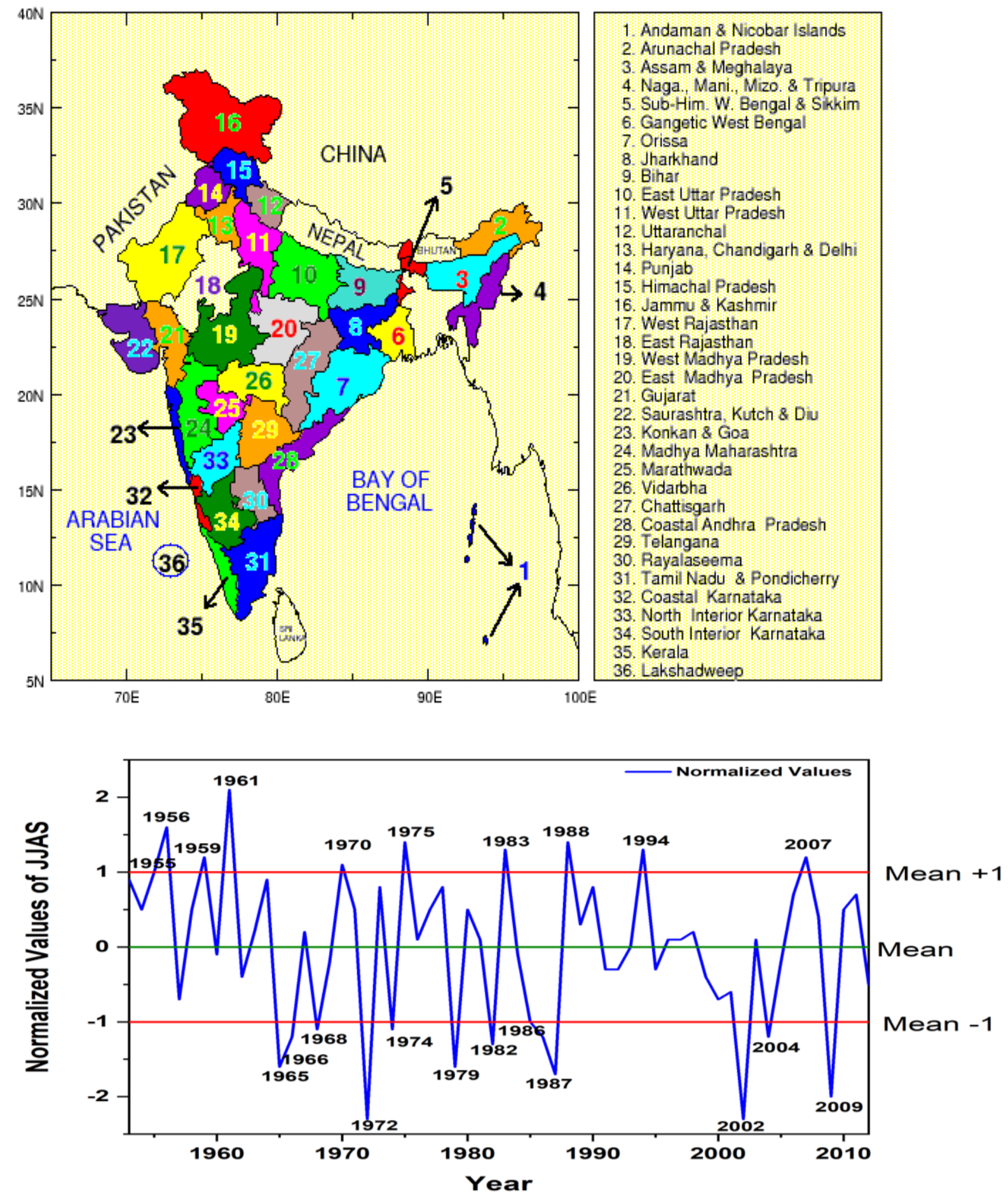

Figure 1(a): Meteorological subdivisions of India and (b). The time series of the Normalized values of the all-India summer monsoon rainfall (AISMR) (1953-2012). 

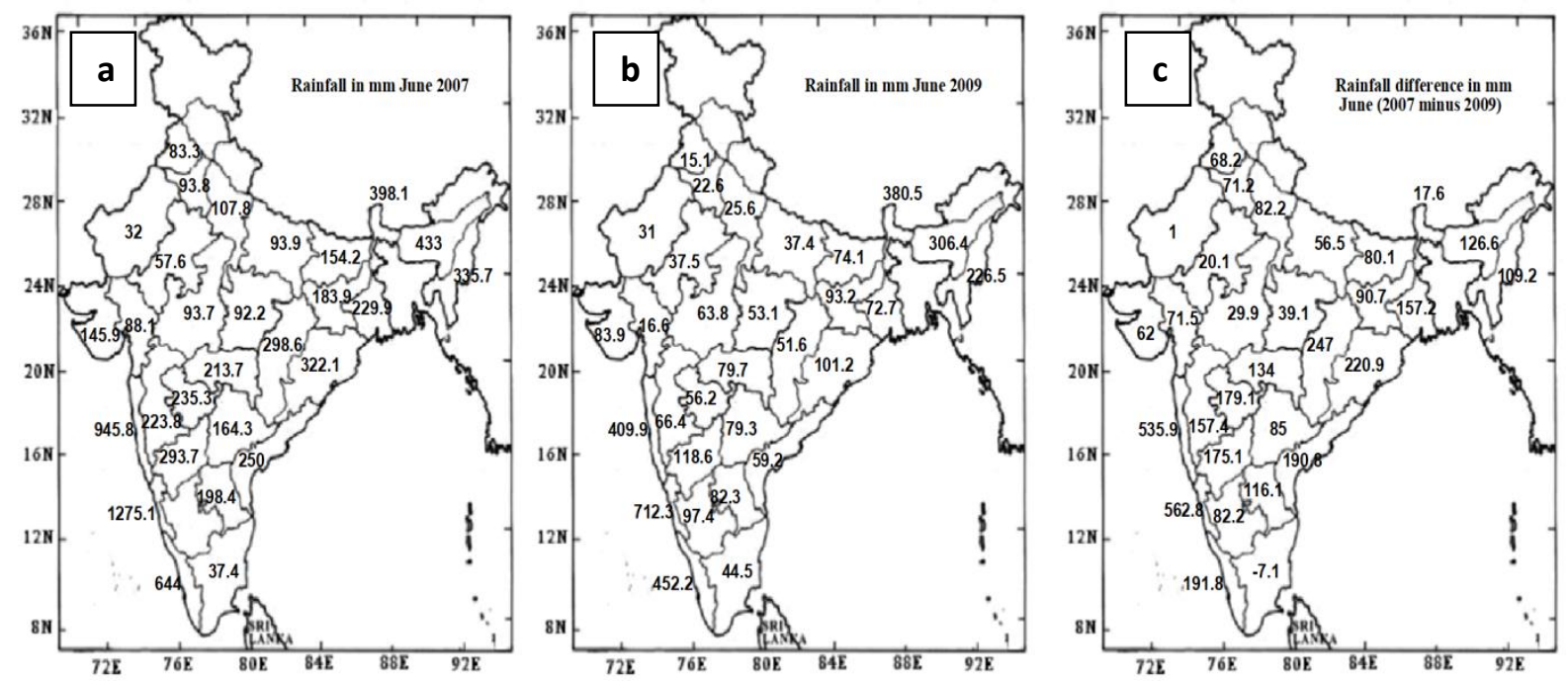

Figure 2: Rainfall (in mm) in June for (a) 2007, (b) 2009 and (c) their differences ((a) minus (b)).
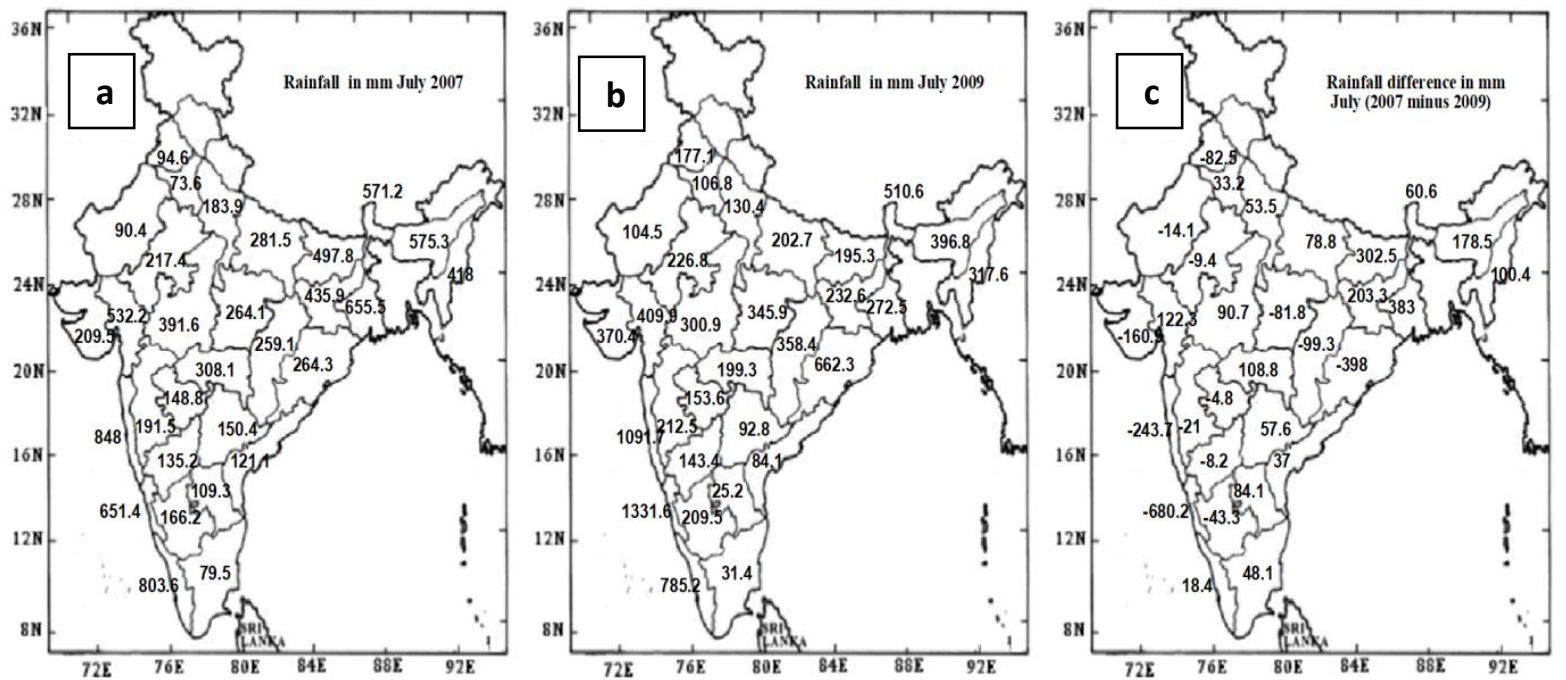

Figure 3: Rainfall (in mm) in July for (a) 2007, (b) 2009 and (c) their differences ((a) minus (b)). 

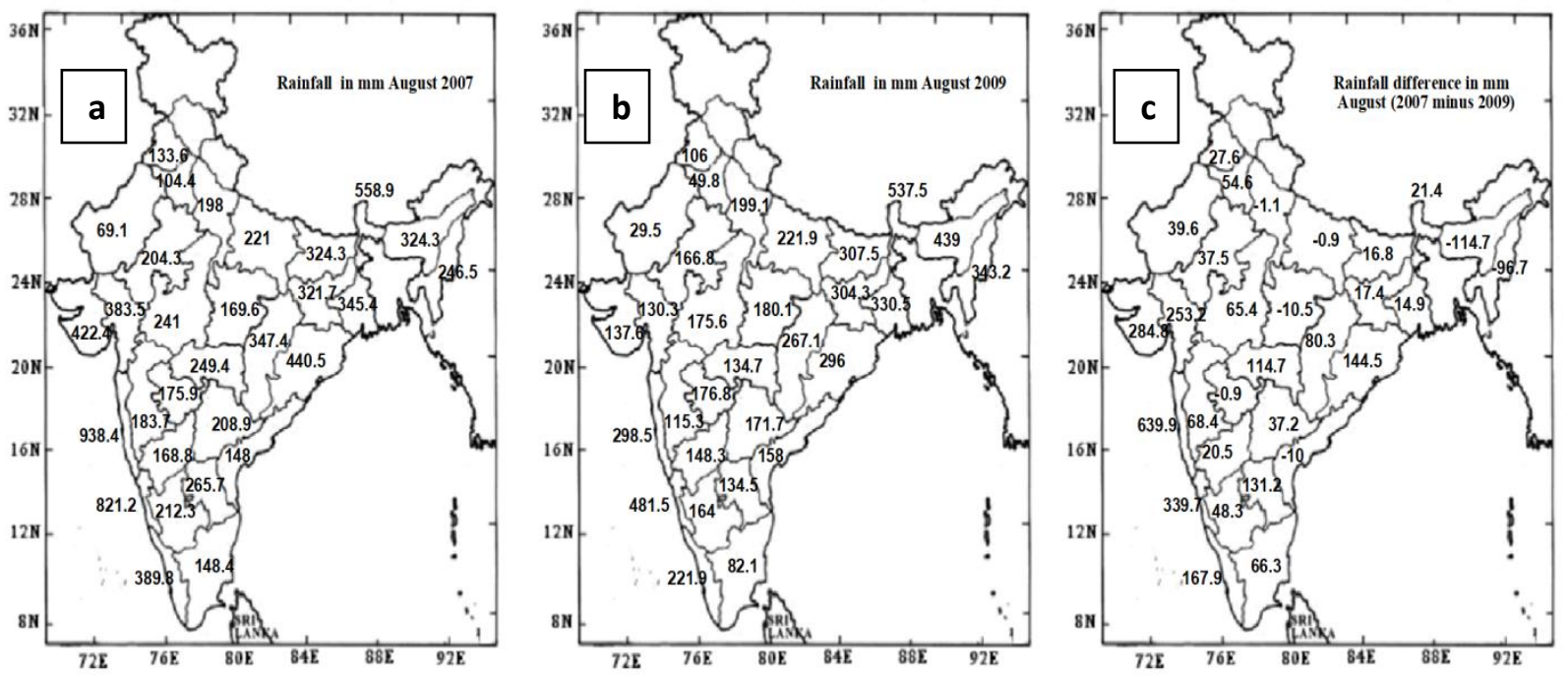

Figure 4: Rainfall (in mm) in August for (a) 2007, (b) 2009and (c) their differences ((a) minus (b)).
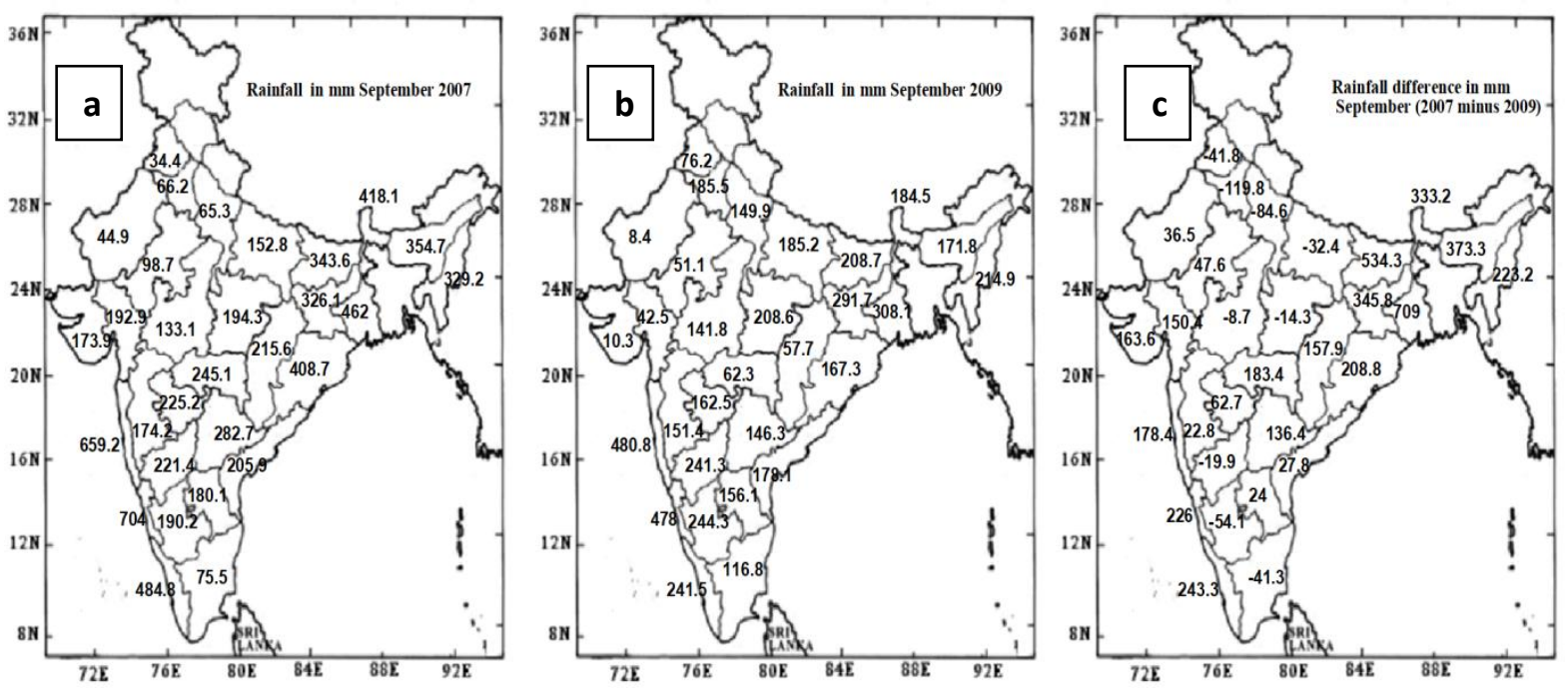

Figure 5: Rainfall (in mm) in September for (a) 2007 and (b) 2009 and (c) their differences ((a) minus (b)). 

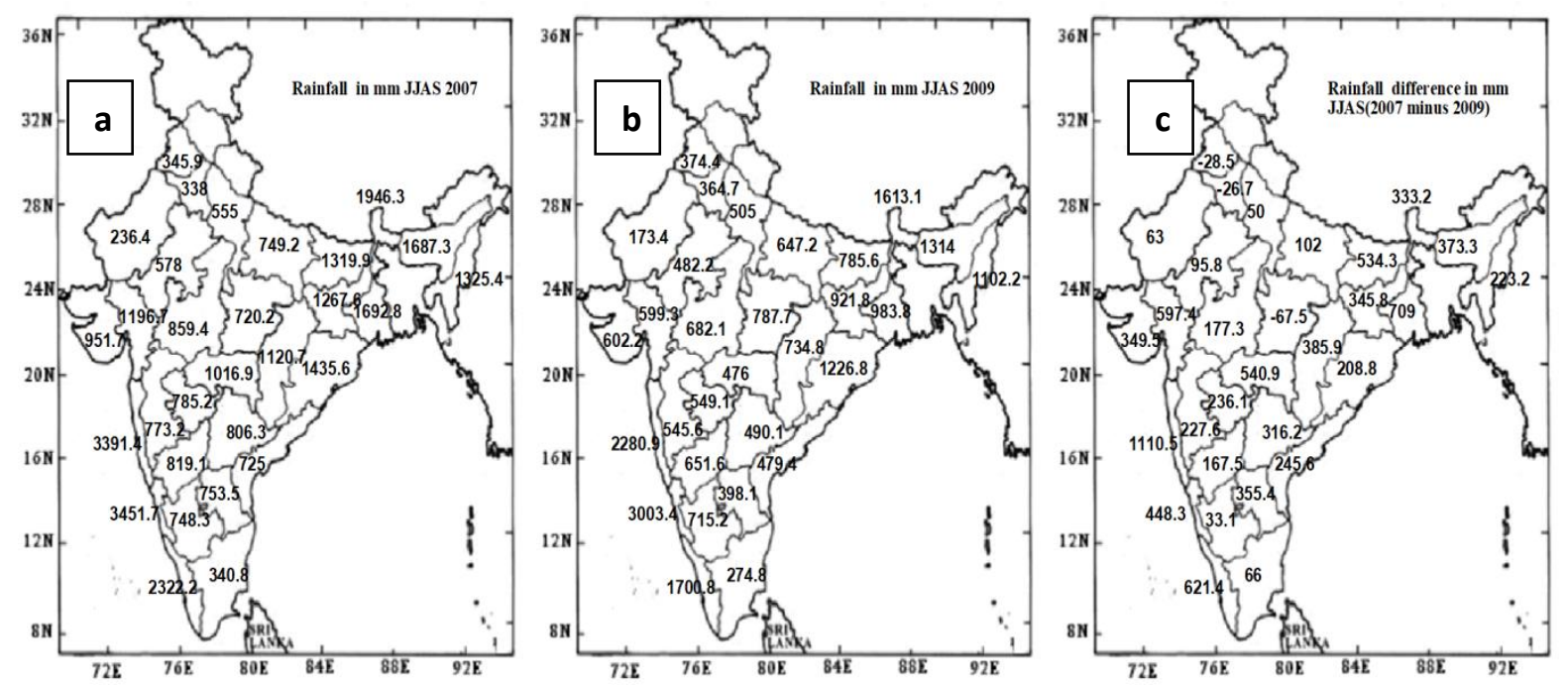

Figure 6: Rainfall (in mm) in summer monsoon season for (a) 2007, (b) 2009 and (c) their differences ((a) minus (b)). 
(a) Latent Heat Flux JJ AS-2007

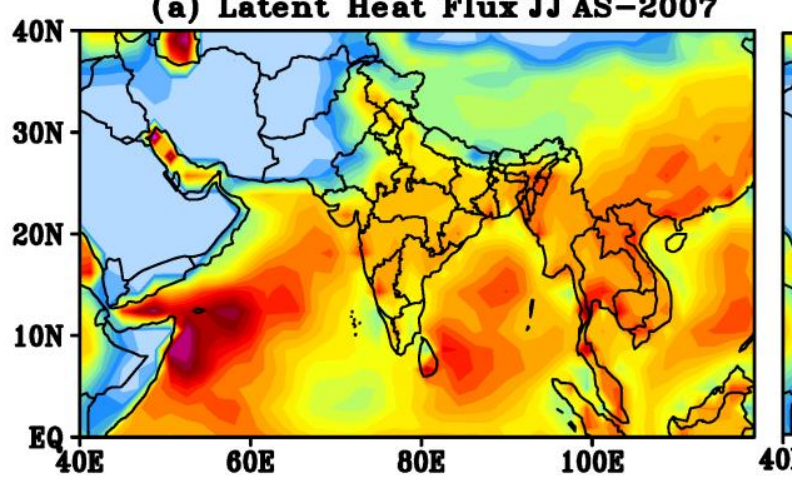

(c) Difference Latent Heat Flux

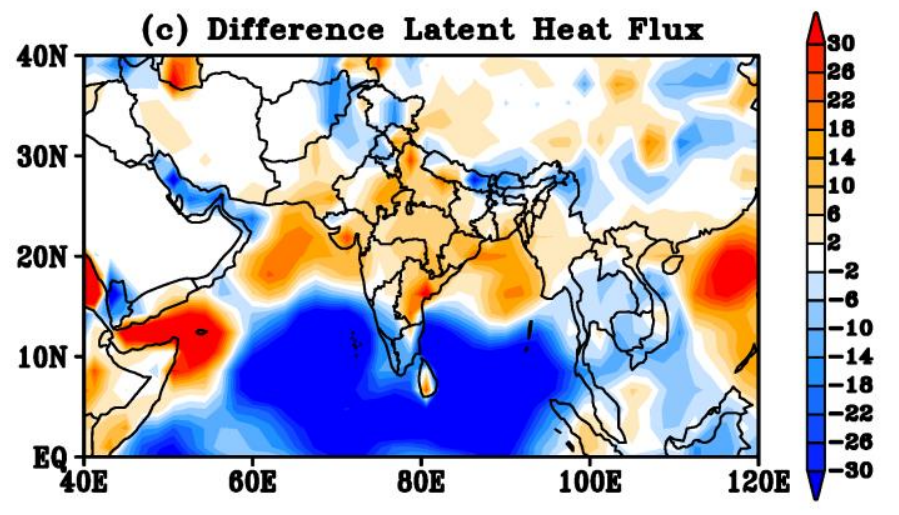

(b) Latent Heat Flux JJ AS-2009

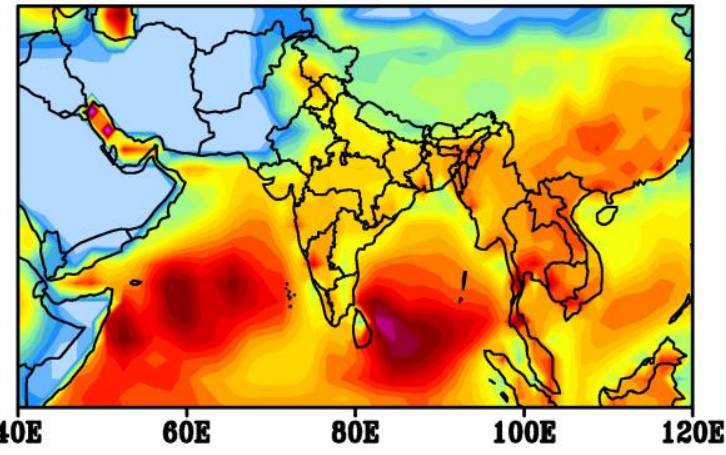

$120 \mathrm{E}$

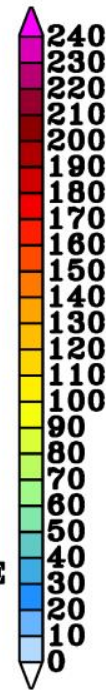

Figure.7: Latent heat flux $\left(\left(\mathrm{w} / \mathrm{m}^{2}\right)\right.$ in summer monsoon for (a) 2007, (b) 2009, and (c) their differences ((a) minus (b)). 

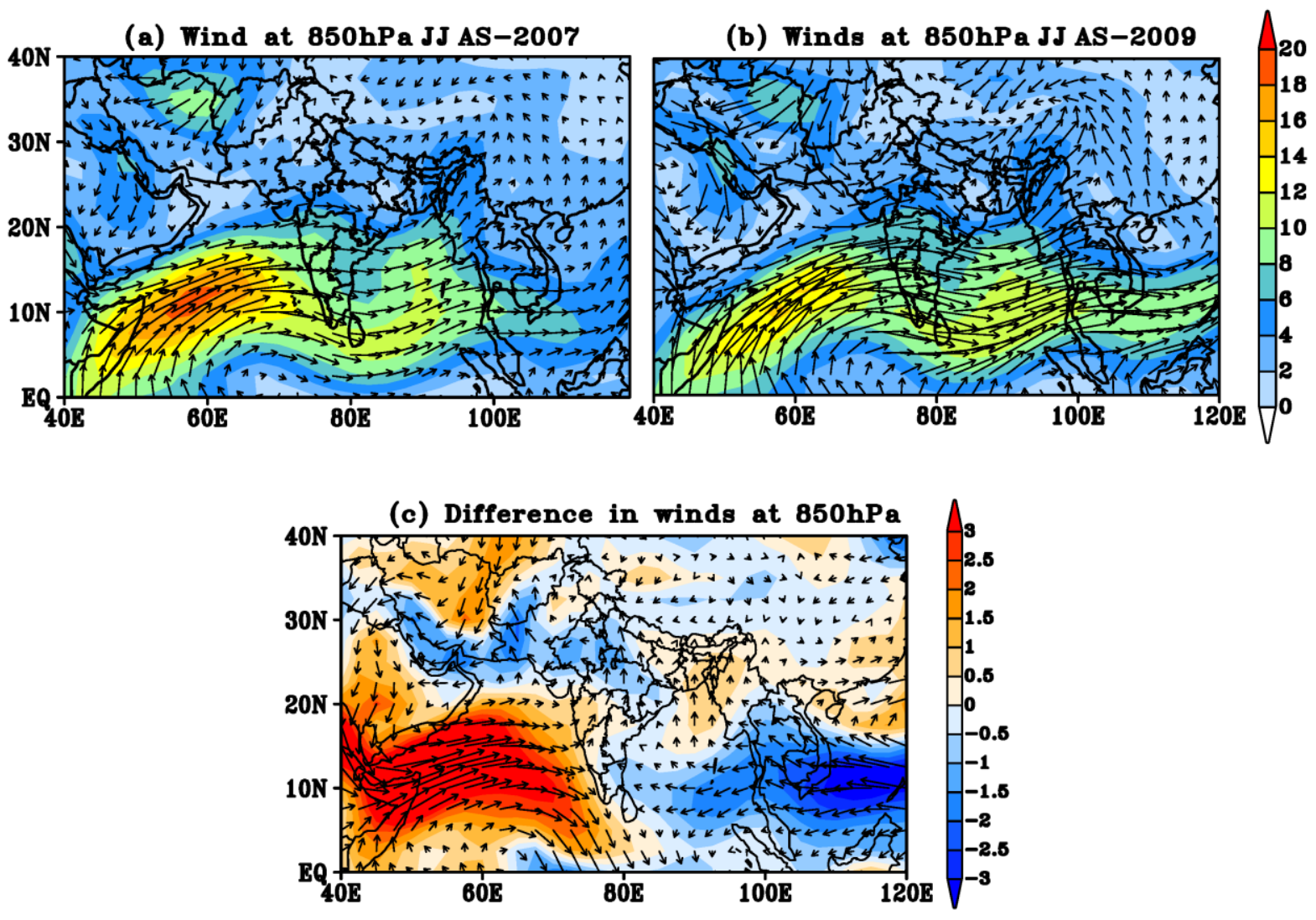

Figure.8: Streamline pattern at $850 \mathrm{hPa}$ in summer monsoon for (a) 2007, (b) 2009, and (c) their differences ((a) minus (b)). 
(a) Wind at $150 \mathrm{hPa} J J \mathrm{AS}-2007$

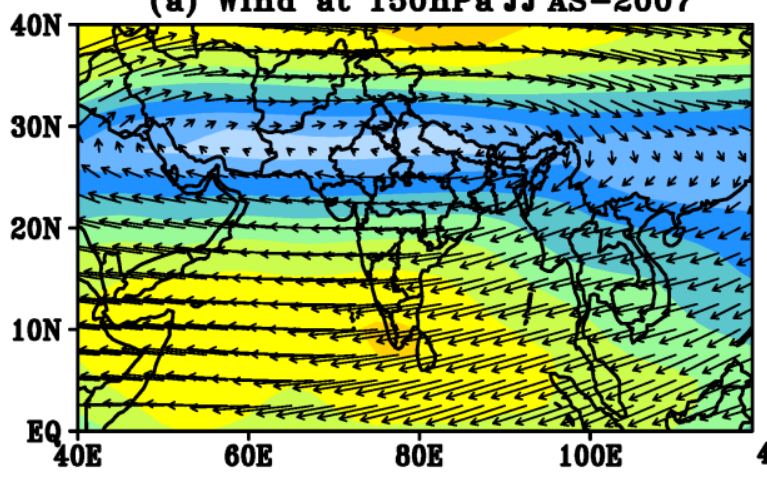

(b) Winds at $150 \mathrm{hPa} \mathrm{JJ} \mathrm{AS}-2009$

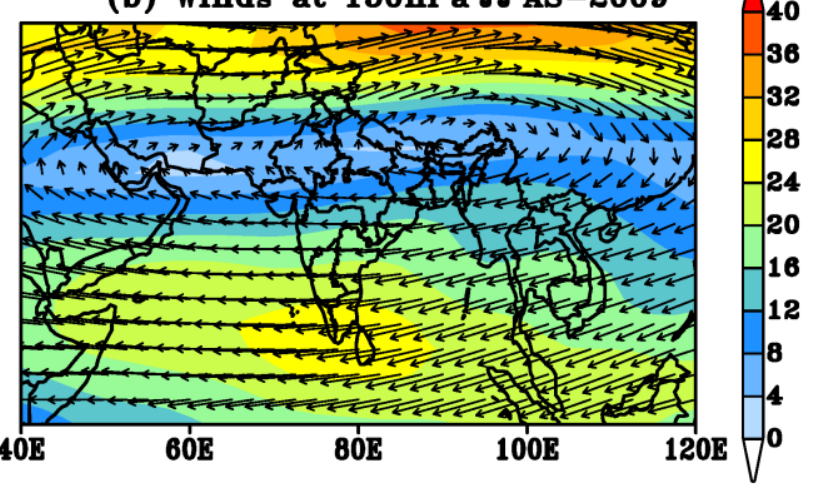

(c) Difference in winds at $150 \mathrm{hPa}$

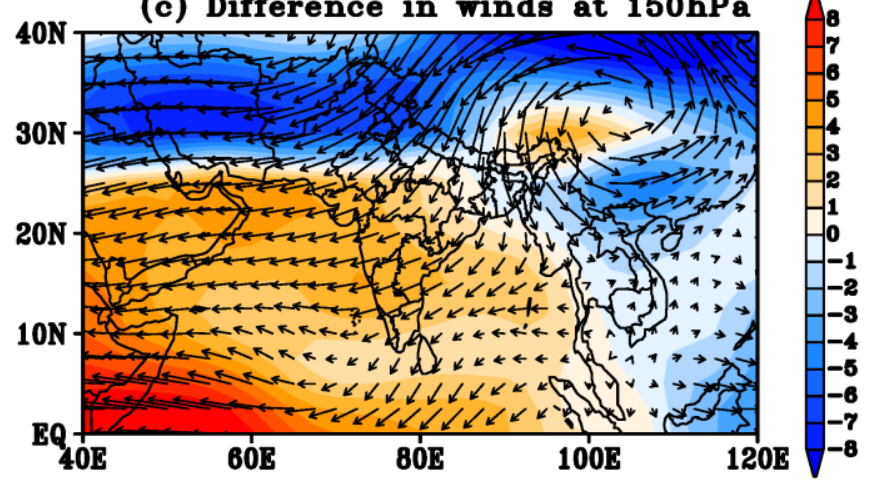

Figure 9: Streamline pattern at $150 \mathrm{hPa}$ in summer monsoon for (a) 2007, (b) 2009 and (c) their differences ((a) minus (b)). 

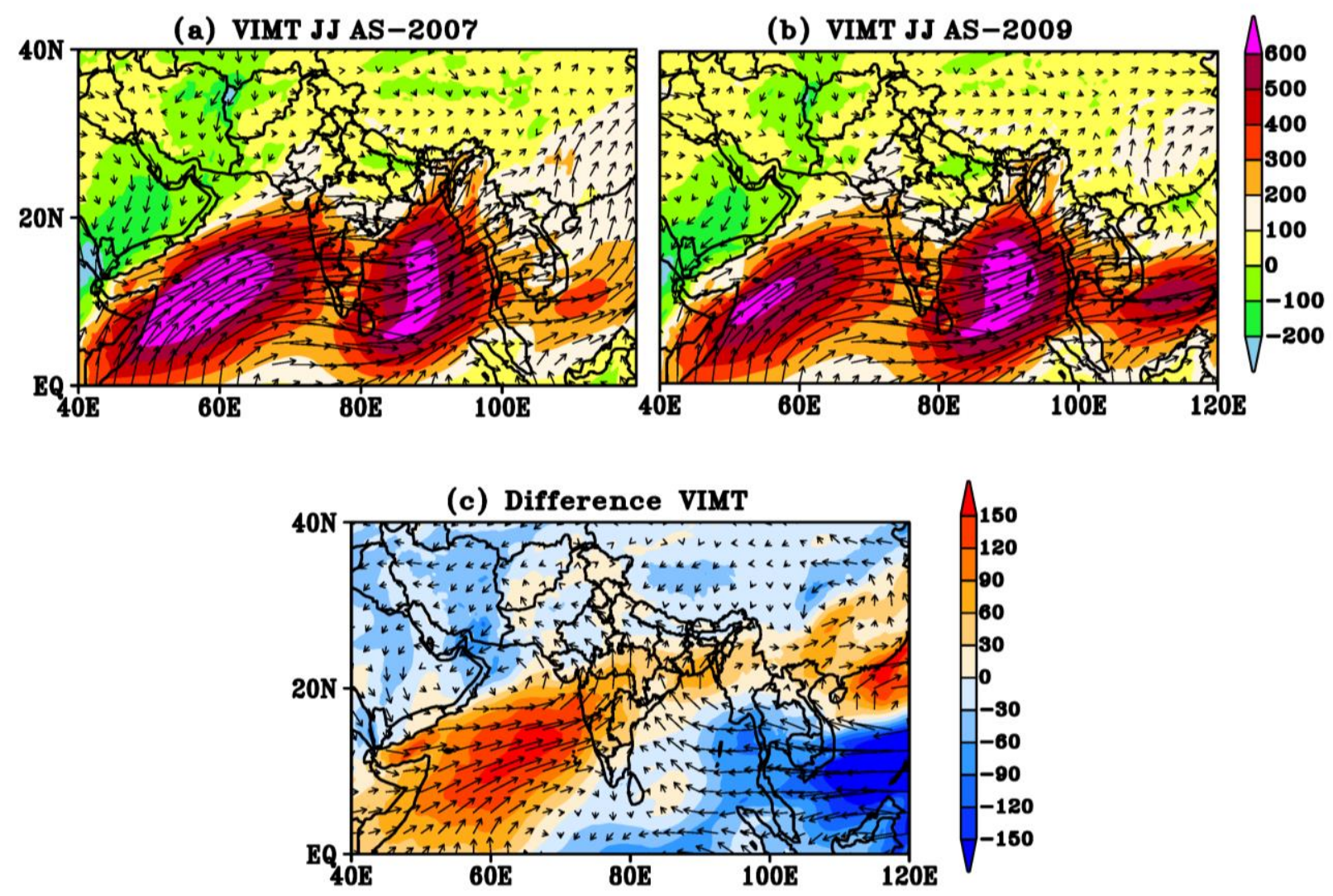

Figure 10: Vertically Integrated Moisture Transport (VIMT) in $\left(\mathrm{kg} \mathrm{m}^{-1} \mathrm{~s}^{-1}\right)$ during monsoon season for (a) 2007, (b) 2009 and (c) their differences ((a) minus (b)). 

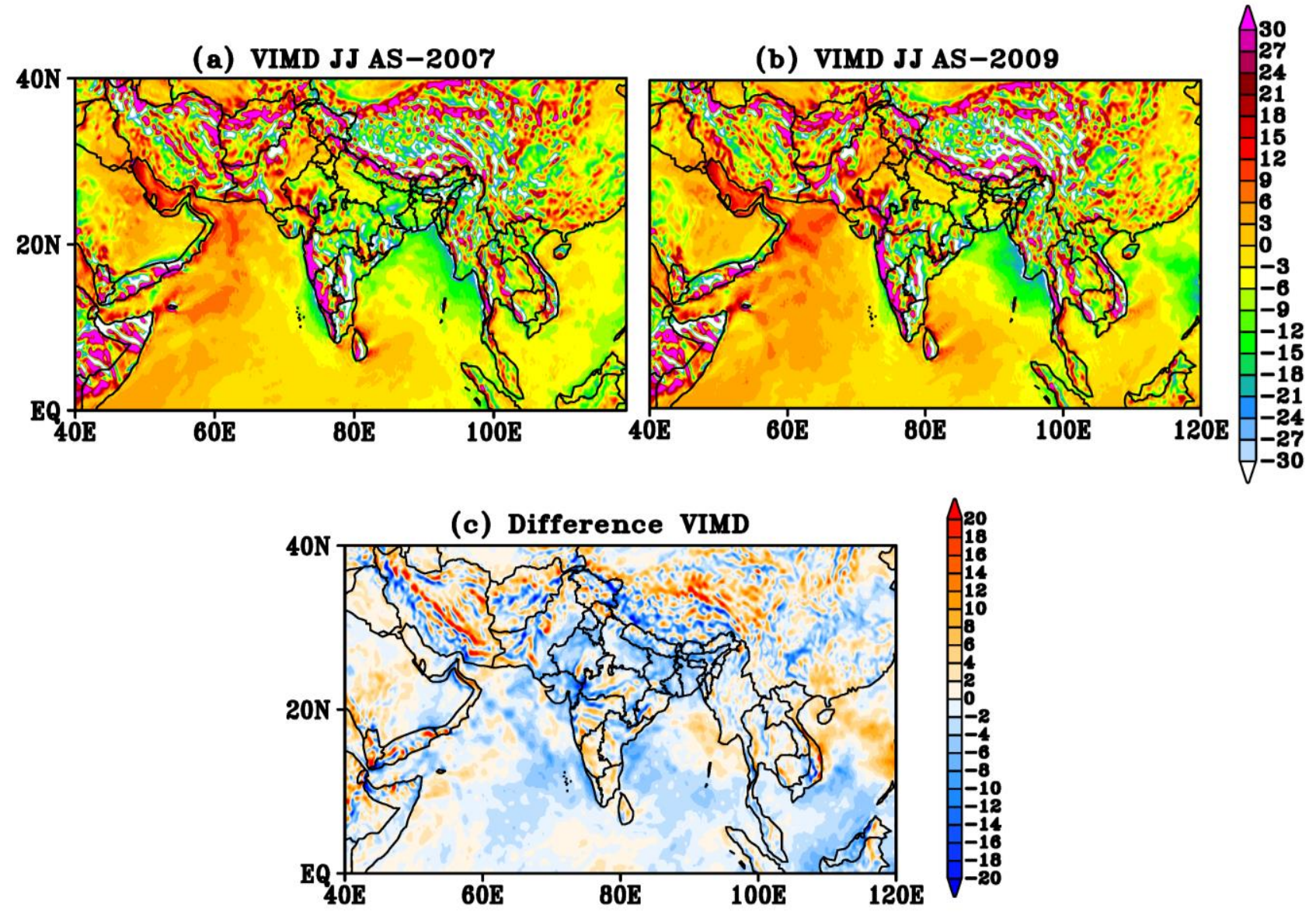

Figure 11: Vertically integrated moisture flux divergence (VIMD) $\left(10^{-5} \mathrm{~kg} \mathrm{~m}^{-2} \mathrm{~s}^{-1}\right)$ in monsoon season for (a) 2007, (b) 2009 and (c) their differences ((a) minus (b)). 